\title{
The Future of the Real Estate Industry of Dubai: The Demand for Real Estates (2000-2020)
}

\section{Abdulkarim Ali Dahan*}

Department of Economics, Ajman University, Ajman, UAE

\begin{abstract}
The main objective of this study is to estimate the demand for real estate (buildings) in Dubai and use this estimate to calculate elasticities and to forecast the demand in the coming years. I have constructed and estimated a simple econometric model. The model was simple due to severe data limitations on useful economic variables.

Linear model was found to best fit the data on the demand for buildings in Dubai. All estimated coefficients are well determined at the $5 \%$ level of significance with signs expected by economic theory. The analyses showed that population and interest rate have no significant effect on the demand for buildings, while price and income have.

The paper concludes that demand for buildings in Dubai grew very rapidly in the past and farther continues growth in the future. The total demand will increase from 8893 building in 2018 to 14328 building in 2020 .

Elasticities are less than one indicating an inelastic demand for real estates. This will not only require significant investments over the coming years, but will require more efforts by the Dubai government to prepare more affordable building blocks, especially for Expo 2020.
\end{abstract}

Keywords: Economics; Estimation; Forecast

\section{Introduction}

As globalization of investments increases, global real estate investors might have to consider other emerging markets and start developing a better understanding of markets such as those of the Gulf Cooperation Council (GCC), especially the United Arab Emirates. The country's economic and political stability has emerged as a safe haven for international investors during regional turmoil in recent years, a trend that has played an important part in keeping the real estate sector on track, especially the housing units.

Because of its strategic location and security, Dubai is attracting people from all around the world to a life of comfort, economical gains and social security. The market of real estate and construction, which was estimated at 49.2 billion AED in 2016, is expected to register a compound annual growth rate outpacing the majority of developed nations around the world.

Studies on demand for buildings in Dubai are relatively rare. There is only one study conducted to forecast the future trends in Dubai housing market [1]. Furthermore, little is done on estimating the demand for buildings in Dubai. This study attempts to fulfill this gap and helps understand this market in Dubai. Specifically, the study aims at empirically estimating the demand for real estates and forecast its future trend.

This paper will also try to explore both the attractiveness level of Dubai's real estate market to global real estate investors, as well as the key cross-border barriers that influence the decisions of those investors when accounting to invest in United Arab Emirates, particularly in Dubai.

The format of this paper is as follows: An overview of the real estate sector and growth in Dubai, the econometric methodology, the estimation of the total demand function for the period 2000-2017 and findings, the estimated equations to predict the demand for the next three years, 2018-2020. Finally, the paper ends with a conclusion and recommendation.

\section{Overview}

Over the past 17 years, Dubai has recorded significant economic growth, primarily driven by the non-oil sectors. The real estate sector was designated as one of the driving force of its economic growth. Only $6 \%$ of Dubai's GDP comes from the oil sector with the dominant sector now being trade and repairing services, which in 2016 counted for $27.5 \%$, emphasizing Dubai's dominant position as a trade center. Other major drivers of economic growth include real estate and construction, $13 \%$, transportation and storage, $11.6 \%$, and financial and insurance activities, $10.6 \%$.

Because of this high growth, Dubai has seen a pronounced improvement in conditions, with market confidence returning, occupancy rates on the rise and hotel and retail segments benefiting from an upswing in tourist numbers. Meanwhile, similar positive news emerged from other emirates in the UAE.

The market for completed buildings, which was estimated at 28.3 billion UAD in 2017, is expected to register high growth rate in the coming years. The demand for completed units increased from 1917 unit in 2000 to 7271 unit in 2017, increasing at an average rate of $8.16 \%$ a year.

\section{Related Work}

Early econometric work on housing models was by Fair who also suggests a housing-starts model where disequilibrium concepts and the

*Corresponding author: Abdulkarim Ali Dahan, Department of Economics, Ajman University, Ajman, UAE, Tel: +97167056505; E-mail: a.dahan@ajman.ac.ae

Received October 01, 2018; Accepted November 20, 2018; Published November 27, 2018

Citation: Dahan AA (2018) The Future of the Real Estate Industry of Dubai: The Demand for Real Estates (2000-2020). J Glob Econ 6: 317. doi: 10.4172/23754389.1000317

Copyright: (c) 2018 Dahan AA. This is an open-access article distributed under the terms of the Creative Commons Attribution License, which permits unrestricted use, distribution, and reproduction in any medium, provided the original author and source are credited. 
mortgage market-a very important determinant of U.S. construction at the time-can influence the housing cycle. Interestingly, he identifies asymmetric effects as being potentially important in explaining variations in prices and volumes in the housing market [2,3].

In his study, A Joint Model of Tenure Choice and Demand for Housing in the City of Karachi, Nuzhat Ahmad estimated a joint model of tenure choice and demand for housing for the city of Karachi, Pakistan, using a two-stage estimation procedure, which included permanent income and demographic variables in the analysis [4]. $\mathrm{He}$ concluded that, ownership rates are high in Karachi and ownership is more likely with increases in permanent income, age, household size and residence in the unauthorized areas. Permanent income, transitory income, age and education of the head significantly affect the consumption of housing both for renter and owner households.

Ermisch et al. in their study, The Price Elasticity of Housing Demand in Britain: Issues of Sample Selection have estimated the price and income elasticities of housing demand for six British conurbations [5]. The estimates are derived from a hedonic house price equation. The price elasticity estimates are found to be robust with respect to alternative specifications and corrections for sample selection bias. They concluded that, the price elasticity of housing demand is an important parameter for the assessment of the effects of policy changes.

Hansen et al. in their study entitled "The Income Elasticity of Demand for Housing: Evidence from Concentration Curves" have applied techniques developed in the literature on income and consumption distribution to estimate income elasticities of housing demand [6].

Federico Perali and Chavas in a study titled "Estimation of Censored Demand Equations from Large Cross-Section Data” developed an econometric methodology to estimate a system of censored demand equations using a large cross-section data from Colombian urban households $[7,8]$.

To identify the impact of social interactions, Ioannides and Zabel estimated a model of housing demand with neighborhood effects [9]. They found evidence of both endogenous and contextual neighborhood effects. They reported two alternative sets of estimates for neighborhood effects that differ in terms of the instruments they use for estimating the model. When the endogenous neighborhood effect is large, the respective contextual effects are weak, and vice versa. They found that elasticity of housing demand with respect to the mean of the neighbors' housing demands (the endogenous effect) ranges from 0.19 to 0.66 and is generally very significant. The contextual effects are also very significant. A key such effect, the elasticity with respect to the mean of neighbors' permanent incomes ranges from 0.17 to 0.54 .

In their study in Berger-Thomson and Ellis modeled the housing markets in Australia, the United States, the United Kingdom and Canada using a structural three-stage least squares system [10]. They related the variations in the housing sector's cyclicality and sensitivity to variation movements in the interest rates and said it is possible that construction lags generate intrinsic cyclicality in this sector. They concluded that although the housing sector is generally considered to be more interest-sensitive than the economy as a whole, the degree of this sensitivity seems to vary between countries and through time.

Mark et al. in their study "A Cross-Section Analysis of the Income Elasticity of Housing Demand in Spain" estimated the income elasticity of the demand for housing in Spain based on the cross-section of prices and income in fifty Spanish provinces from 1996 to 2002 [11-13]. In comparison to long-run equilibrium models fitted with time-series data, their results showed a much weaker role of income growth as a vehicle for house price increases in the long run. According to their estimates, the rate of growth of house prices in Spain between 1998 and 2003 points to a real estate bubble with prices above the long term equilibrium level $[14,15]$.

Raya et al. in their study "Price and income elasticities of demand for housing characteristics in the city of Barcelona" have used the information of properties appraised in the city of Barcelona (19982001) to estimate price and income elasticities of demand for housing characteristics $[16,17]$. They employed a two-stage approach to estimate hedonic price equations for different districts. They concluded that, by knowing the price, cross and income elasticities of housing characteristics they can make policy recommendations about the type of housing units, which are the most desirable to be subsidized.

Attanasio et al. in their study "Modelling the Demand for Housing over the Lifecycle, in the UK" have presented a life-cycle model [18]. Simulations of their model shows how sensitive individual demand for housing is to the parameters of the house price process, and the income process, and also to the tightness of mortgage related borrowing constraints. The level of house prices and earnings have marked effects on behavior. When incomes go up the demand for housing shows the expected increase. More surprisingly, when the price of housing (i.e. of houses and flats) goes up, this leads to a fall in demand for houses, but to an increase in the demand for flats [19].

Patrick et al. in their study "A Dynamic Model of Housing Demand" have used data from the Panel Study of Income Dynamics (PSID) they specify, estimate and simulate a dynamic structural model of housing demand [20]. Their model generalizes previous applied econometric work by incorporating realistic features of the housing market including non-convex adjustment costs from buying and selling a home, credit constraints from minimum down payment requirements and uncertainty about the evolution of incomes and home prices. They argued that these features are critical for capturing salient features of housing demand observed in the PSID [21-23].

Another study titled "A Dynamic Model of Demand for Houses and Neighborhoods" by Patrick Bayer et al. was conducted [24]. The study developed a dynamic model of neighborhood choice along with a computationally light multi-step estimator. The proposed empirical framework captures observed and unobserved preference heterogeneity across households and locations in a flexible way. The authors estimated the model using a newly assembled data set that matches demographic information from mortgage applications to the universe of housing transactions in the San Francisco Bay Area from 1994 to 2004 [25]. The results provide the first estimates of the marginal willingness to pay for several non-marketed amenities-neighborhood air pollution, violent crime, and racial composition in a dynamic framework. Comparing these estimates with those from a static version of the model highlights several important biases that arise when dynamic considerations are ignored.

\section{Research Methodology}

The distributed lag and the stock of adjustment theory of demand will be adopted in this section. This model will be adopted because it allows for distinguishing short and long run effects (elasticities) of changes in income, price, and other explanatory variables on the demand for housing.

Stock of adjustment theory assumes that at price $P_{t}$ and income 
Citation: Dahan AA (2018) The Future of the Real Estate Industry of Dubai: The Demand for Real Estates (2000-2020). J Glob Econ 6: 317. doi: $10.4172 / 2375-4389.1000317$

Page 3 of 5

$Y_{t}$ the consumer has a desired level of consumption $Q^{*}$, but the actual change in consumption $Q_{t}-Q_{t-1}$ is proportional to the difference between the desired consumption $Q^{*}$ and $Q_{t-1}$ :

$$
\begin{aligned}
& Q_{t}^{*}=B_{0}+B_{1} Y_{t}+B_{2} P_{t}+U_{t} \\
& Q_{t}-Q_{t-1}=s\left(Q_{t}^{*}-Q_{t-1}\right)
\end{aligned}
$$

Where: $0<\mathrm{s}<1$ the speed of adjustment

By substituting eqn. (1) in eqn. (2), we have:

$$
Q_{t}-Q_{t-1}=s\left(B_{0}+B_{1} Y_{t}+B_{2} P_{t}+U_{t}-Q_{t-1}\right)
$$

By arranging eqn. (3), we get:

$$
\begin{aligned}
& Q_{t}=s B_{0}+s B_{1} Y_{t}+s B_{2} P_{t}+(1-s) Q_{t-1}+s U_{t} \\
& Q_{t}=a_{0}+a_{1} Y_{t}+a_{2} P_{t}+a_{3} Q_{t-1}+e_{t}
\end{aligned}
$$

Where: $a_{0}=s B_{0}$

$$
\begin{aligned}
& a_{1}=s B_{1} \\
& a_{2}=s B_{2} \\
& a_{3}=(1-s) \\
& e_{t}=s U_{t}
\end{aligned}
$$

The model also can be formulated in logarithms as:

$\ln Q_{t}=a_{0}+a_{1} \ln Y_{t}+a_{2} \ln P_{t}+a_{3} \ln Q_{t-1}+e_{t}$

Where $a_{1}$ and $a_{2}$ denote elasticities in the short run.

When this model is not appropriate or is statistically insignificant, the following regression model will be used instead:

$$
Q_{t}=f\left(Y_{t}, P_{t}, X_{t}\right)+e_{t}
$$

Where:

$$
\begin{aligned}
& Q_{t=} \text { Demand for real estates (buildings) } \\
& Y_{t=} \text { Income (GDP) per capita } \\
& P_{t=} \text { Average Price per building } \\
& X_{t=} \text { Any other variable affecting the demand for housing } \\
& e_{t}=\text { Error term. }
\end{aligned}
$$

In this model, the most variables that could influence real estate's demand, as discussed by many researchers, are own price, a measure of economic activity, interest rate, and population. The variables that may affect the demand should be selected and the final model will be reached after eliminating the unimportant and insignificant variables.
Due to data limitation, time series representing the period 2000 to 2017 were utilized in this study [26]. The data for GDP per capita, at constant prices, number of completed buildings, average price per building, interest rate, and population are obtained from the Dubai Statistics Center.

\section{Model Estimation and Findings}

Simple log model was found to best fit the data available and in an attempt to see the effect of other variables like population, and interest rate, below equation was estimated first but result showed that multicollinearity exists among these variables; therefore they were dropped from the analysis.

After correcting for the autocorrelation problem, the equation was re-estimated using income per capita, average price, and lag demand, as shown in equation below.

$$
\begin{aligned}
& \log Q_{t}=2.861+0.85 \log g d p(Y)-0.67 \log \operatorname{Pr} \text { ice }(P)+0.674 \log Q_{t-1} \\
& (1.1) \\
& R^{2}=0.74, D W=1.94,(2000-2017)
\end{aligned}
$$

Although, the value of $\mathrm{R}^{2}$ is quite low, the estimated equation shows that these variables explain about $74 \%$ of the variation in the demand for real estates. The value of the D-W statistic is acceptable and all estimated coefficients have the signs expected by economic theory, with $t$ statistics in parenthesis, and well determined at the 5\% level of significance except the intercept nevertheless; it was kept in the estimated equation for conceptual completeness $[27,28]$.

Overall, the model fits and explains real estates' demand satisfactorily and indicates that, beside gross domestic product and price, there are some other factors that might affect the demand for real estates in Dubai. The preferred solution to this problem is first, to increase the number of data periods and second, to include the missing variables in the model by introducing auxillary variables. Actual and fitted demand are shown in Figure 1.

\section{Forecasting Techniques and Methodology}

To forecast the demand for real estates in Dubai, individual variables (gross domestic product and price) should be analyzed and their trends for the future should be forecasted first. This forecast will be made based on the above estimated regression equation using the historical data from year 2000 to year 2017. Using the forecast of individual variables, the demand will be forecasted for the period of 2018-2020.

The projection methodology employed in this study is very

\section{Completed Buildings in Dubai 2000 - 2017}

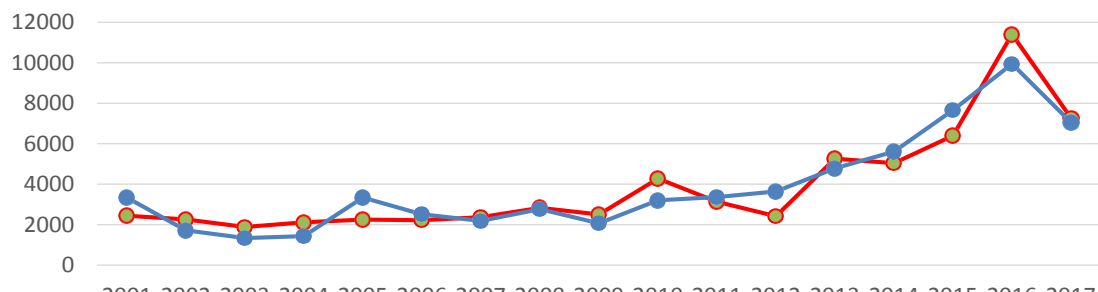

20012002200320042005200620072008200920102011201220132014201520162017 
Citation: Dahan AA (2018) The Future of the Real Estate Industry of Dubai: The Demand for Real Estates (2000-2020). J Glob Econ 6: 317. doi: 10.4172/2375-4389.1000317

Page 4 of 5

\begin{tabular}{|c|c|c|c|}
\hline Year & $\begin{array}{c}\text { First scenario } \\
\text { GDP per capita } \\
\mathbf{g = ( - 1 . 9 8 \% )}\end{array}$ & $\begin{array}{c}\text { Second scenario } \\
\text { GDP per capita } \\
\mathbf{g = 1 0 . 5 \% ~ ( 2 0 1 7 - 2 0 2 0 )}\end{array}$ \\
\hline 2018 & 134160 & 149968 & $\begin{array}{c}\text { First scenario } \\
\text { Average price per building } \\
\mathbf{g = ( - 1 5 . 3 \% )}\end{array}$ \\
\hline 2019 & 131504 & 162565 & 2254313 \\
\hline 2020 & 128900 & 177846 & 1909403 \\
\hline
\end{tabular}

Table 1: Projection of the independent variables, 2018-2020.

\begin{tabular}{|c|c|c|}
\hline Year & $\begin{array}{c}\text { First scenario } \\
\text { Number of completed buildings }\end{array}$ & $\begin{array}{c}\text { Second scenario } \\
\text { Number of completed buildings }\end{array}$ \\
\hline 2018 & 8893 & 9701 \\
\hline 2019 & 11170 & 14186 \\
\hline 2020 & 14328 & 22026 \\
\hline
\end{tabular}

Table 2: Projected completed buildings in Dubai, 2018-2020.

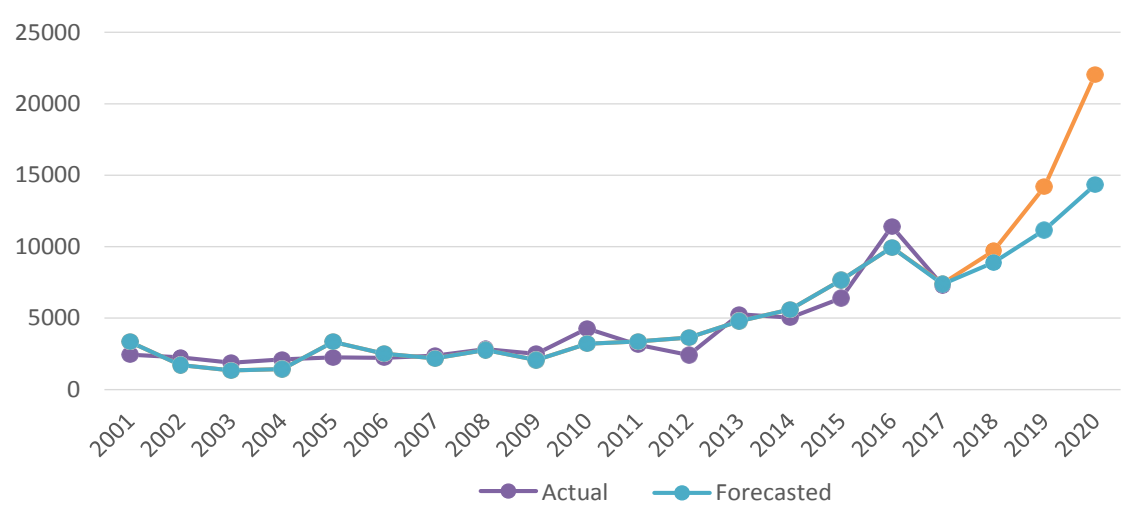

Figure 2: Actual and projected number of completed buildings in Dubai, 2018-2020.

simplistic in that projections are basically driven by scenarios for income growth rate and price growth rate. Given scenarios for these variables, the future demand will be forecasted.

The first scenario examined in this study, assumes that per capita GDP and average price per building will continue to grow to the year 2020, at 2010-2016 average annual growth rates.

On the other hand, the second scenario examined is of a high growth rate of per capita GDP because of hosting Expo 2020, which is likely to attract substantial foreign investment into the UAE, and will build upon Dubai's core economic sectors of financial services, construction, tourism, and hospitality. This growth rate is due to the expected potential impact of the World Expo on Dubai. Dubai Expo 2020 is likely to boost Dubai's economic growth to an average 6.4 percent a year from 2014 to 2016 and potentially to 10.5 percent by 2020 [29]. These figures are calculated based on the total spending by the Dubai government, participants, visitors, and general commercial activities related to the event. All growth rates are calculated based on equation (15), and the projected values are presented in Table 1.

$$
X_{2016}=X_{2010}(1+g)^{n}
$$

Where:-

$$
\begin{aligned}
& X=\text { The value of the variable } \\
& G=\text { Growth rate } \\
& n=\text { Number of periods. }
\end{aligned}
$$

Given scenarios for those variables, the projected demands for housing are shown in Table 2 and Figure 2 respectively.

\section{Conclusion}

The results of this research conclude that, the real estate's demand in Dubai grew very rapidly during the last seventeen years, and this growth is expected to grow farther in the coming years. The demand for buildings is projected to increase during the projected periods. The total demand will increase from 8893 building in 2018 to 14328 building in 2020, according to the first scenario, while the demand, according to the second scenario, will increase from 9701 building in 2018 to 22026 building in 2020 , respectively.

The analysis showed that, GDP and price elasticities are less than one indicating an inelastic demand for real estates with elasticities of $(0.85)$ and $(-0.67)$, respectively. The result of this analysis suggests that, demand for real estates will keep growing further in the coming years and more investments, in this sector, are needed to meet that demand. Further, policy makers should expect further strains on government's budgets to prepare more affordable building blocks and services, especially for Expo 2020.

\section{References}

1. Dahan AA (1996) Economic Analysis of Energy Consumption in Yemen University of Arizona, Tucson, USA

2. Fair RC (1972) Disequilibrium in Housing Models. J Financ 27: 207-221.

3. Fair RC, Jaffee DM (1972) Methods of Estimation for Markets in Disequilibrium Econometrica 40: 497-514.

4. Ahmad N (1994) A Joint Model of Tenure Choice and Demand for Housing in the City of Karachi. Urban Studies, 31: 1691-1706.

5. Ermisch JF, Findlay J, Gibb K (1996) The Price Elasticity of Housing Demand in Britain: Issues of Sample Selection. J Hous Econ 5: 64-86. 
Citation: Dahan AA (2018) The Future of the Real Estate Industry of Dubai: The Demand for Real Estates (2000-2020). J Glob Econ 6: 317. doi: 10.4172/2375-4389.1000317

Page 5 of 5

6. Hansen J, John P, Formby, Smith WJ (1996) The Income Elasticity of Demand for Housing: Evidence from Concentration Curves. J Urban Econ 39: 173-192.

7. Federico Perali, Jean-Paul Chavas (2000) Estimation of Censored Demand Equations from Large Cross-Section Data. Am J Agric Econ 82: 1022-1037.

8. Bell M, Dean C, Blake M (2000) Forecasting the pattern of urban growth with PUP: aweb-based model interfaced with GIS and 3D animation. Comput Environ Urban Syst 24: 559-581.

9. Ioannides YM, Zabel JE (2001) Neighborhood Effects and Housing Demand. Dep Econ 18: 563-584.

10. Berger-Thomson L, Ellis L (2004) Housing Construction Cycles and Interest Rates. Res Discuss Pap 2004-08.

11. Kranz DF, Mark T, Hon A (2006) Cross-Section Analysis of the Income Elasticity of Housing Demand in Spain. J Real Estate Financ Econ 32: 449-470.

12. Lewis D, Archibald X, Howard S (2008) An ardl model of the demand for housing in barbados, 152 / business. Financ Econ Emerg Econ 3: 151-174.

13. Majid MZA, Yahya K (2002) Forecasting of low cost housing demand in urban areas: artificial neural network and ARIMA model approach, Proceedings: 2nd International Conference on Systems Thinking in Management, Apri 3-5,University of Salford, Manchester, University of Salford Press, 5: 14-19.

14. Mills A, Harris D, Skitmore RM (2003) The accuracy of housing forecasting in Australia, Engg Constr Archit Manag10: 245-253.

15. Kenny $G$ (1999) Modelling the demand and supply sides of the housing market: evidence from Ireland. Econ Model 16: 389-409.

16. Raya Vilchez JM, Garcia J (2010) Price and income elasticities of demand for housing characteristics in the city of Barcelona. Reg Stud 45: 597-608.

17. Goh BH (1999) An evaluation of the accuracy of the multiple regression approach in forecasting sectoral construction demand in Singapore. Constr Manage Econ 17: 231-241.

18. Attanasio OP, Bottazzi R, Low HW, Nesheim L, Wakefield M (2012) Modelling the Demand for Housing over the Lifecycle. Rev Econ Dyn 15: 1-18.

19. Mulder $\mathrm{CH}$ (2006) Population and housing: A two sided relationship. Demogr Res 15: 401-412.

20. Patrick B, Dirk K, Phoebe C, Daniel M (2013) A Dynamic Model of Housing Demand: Estimation and Policy Implications. Int Econ Rev 54: 409-442.

21. Belenson SM, Kapur KC (1973) An algorithm for solving multicriterion linear programming problems with examples J Oper Res Q 24: 65-77.

22. Ben C Arimah (1992) An Empirical Analysis of the Demand for Housing Attributes in a Third World City. Land Econ 68: 366-379.

23. Chiraphadhanakul S, Dangprasert P, Avatchanakorn V (1997) Genetic algorithms in forecasting commercial banks deposits, Proceedings: IEEE Int Conf Intell Process Syst IEEE Press, Central Garden Hotel, Beijing, 23: 116-121.

24. Bayer P, Mcmillan R, Murphy A, Timmins C (2016) A Dynamic Model of Demand for Houses and Neighborhoods. Econometrica, J Econ Soc 84: 893-942.

25. Akintoye AS, Skitmore RM (1994) Models of UK private sector quarterly construction demand. Constr Manage Econ 12: 3-13.

26. Halicioglu F (2005) The Demand for New Housing in Turkey: An Application of the ARDL Model. Paper Prepared for 2005 Bus Econ Soc Int Conf 9: 62-74.

27. Harry H. Kelejian, Wallace E. Oates (1989) Introduction to Econometrics. $3^{\text {rd }}$ (edn.), Principles and Applications.

28. Holder C (1985) An Analysis of the Housing Market in Barbados. Central Bank of Barbados Economic Review 12: 13-19.

29. Dubai to Host Expo 2020 (2014) The Anticipated Economic Boost. Jones Day Publications, Dubai. 